\title{
ATM kinase inhibitor KU-55933 contribution in cisplatin mediated HeLa proliferation
}

\author{
Devyani Bhatkar, Ajay Kumar, Devashree Jahagirdar, Shruti Purohit, Nilesh Kumar Sharma * \\ Cancer and Translational Research Lab, Dr. D.Y Patil Biotechnology \& Bioinformatics Institute, \\ Dr. D.Y. Patil Vidyapeeth, Pune, Maharashtra, India, 411033 \\ *Corresponding author E-mail: nilesh.sharma@dpu.edu.in
}

\begin{abstract}
Several approaches including chemotherapy and radiation therapies are being at the forefront to treat various types of cancer including cervical cancer. However, the success and failure of genotoxic based therapy is attributed to aberrant ability of carcinoma to patch up genomic breaks. Here, we have used cisplatin as a genotoxic drug model and HeLa as in vitro carcinoma model due to less responsiveness and resistance of HeLa against cisplatin. Here, attempts are made to investigate the effects of DNA double strand break inhibitor KU-55933 against the cisplatin cell growth and cytotoxicity. Following experiments namely in vitro plasmid DNA metabolizing, Trypan blue dye exclusion, MTT, and PI based Flow cytometery PI assays were conducted to study cell growth and cytotoxicity effects. Based on the cell viability and PI based staining data, results remarked that KU-55933 combined with cisplatin could bring convincing cell growth arrest in HeLa. The reduction in HeLa proliferation was noticed from 70\% to 30\% in case of KU-55933 added with cisplatin over cisplatin alone. However, we noticed none apoptosis based cell cytotoxicity in case of cisplatin alone or combined with the inhibitors. We also observed significant DNA instability in case of KU-55933 treated HeLa lysates added to plasmid DNA substrate over HeLa lysate without KU-55933 treatment. In conclusion, KU-55933 can potentiate low dose of cisplatin response against HeLa. The effect of KU-55933 may not be attributed due to its enhancing the apoptosis way, rather than through cell growth arrest mechanism due to extensive DNA breaks.
\end{abstract}

Keywords: Genotoxic Drug; Double Strand Break; Inhibitor; Carcinoma; DNA Break.

\section{Introduction}

Every year, cervical cancer affects $\sim 500,000$ women worldwide, and $\sim 275,000$ patients die of this disease. Currently, several approaches including chemotherapy and radiation therapies are being at the forefront to treat various types of cancer including cervical cancer (Hanahan and Weinberg, 2000; Schnitt, 2010; Kimbung et al., 2015; Braunstein et al., 2016). Among the potential genotoxic drugs, the use of platin-based drugs have rapidly increased and faced with several challenges including drug resistance and side effects (Inoue et al., 2014; Ha et al., 2014; Tonsing-Carter et al., 2015). The cis-Diaminedichloroplatinum II (cisplatin), an agent commonly used in chemo-radiation, acts by producing DNA inter-strand and intra-strand adducts (Inoue et al., 2014; Ha et al., 2014; Tonsing-Carter et al., 2015; Toulany et al., 2015; Ceccaldi et al., 2015). These crosslinks appear to impair replication, transcription of DNA and potential double-strand DNA breaks in the genome (Zhang et al., 2015; Liu et al., 2015; Ratner et al., 2016).

There are several culprits behind cisplatin drug failure including aberrant DNA repair mechanisms in carcinoma (De Bont and van Larebeke, 2004; Jackson and B artek, 2009; Curtin, 2012; Kelley et al., 2014; Khanna, 2015; Velic et al., 2015; O'Connor et al., 2015; Gavande et al., 2016; Liu et al., 2016; Puigvert et al., 2016). Therefore, sensitization of tumor cells towards chemoradiotherapy is considered via inhibition of the DNA damage response (DDR) and attempted pre-clinically (Jackson, 2002; Lieber, 2010; Chapman et al., 2012; Kavanagh et al., 2013; Apari- cio et al., 2014; Álvarez-Quilón et al., 2014; Jeggo and Löbrich, 2015; Ceccaldi et al., 2016; Hitrik et al., 2016; Mladenov et al., 2016; Samadder et al., 2016).

The DNA double-strand break (DSB) is the principle cytotoxic lesion for ionizing radiation but can also be caused by mechanical stress replication fork halt or other type of DNA lesion due to genotoxic drugs (Albarakati et al., 2015; Andrs et al., 2016; Flores-Pérez et al., 2014; Hong et al., 2015; Huang et al., 2016; Jekimovs et al., 2014; Rajamanickam et al., 2016). Improper repair of a DSB can lead to mutations or to larger-scale genomic instability to induce apoptosis in carcinoma inflicted with genotoxic drug. In the present scenario, to reduce the drug doses and bolster the drug response are prime concern. The noticeable attempts are reported to test certain inhibitors drugs dedicated against double strand break repair proteins including KU-55933, SCR-7, SCR-17 and L1 89 along with the existing genotoxic drug regimen (Hickson et al., 2004; Srivastava et al., 2012; Surovtseva et al., 2016; Sriv astava and Raghavan, 2015; Vecchio and Frosina, 2016; Weterings et al., 2016). Herein, we have attempted to evaluate the modulatory role of KU-55933 towards Cisplatin based HeLa cell cytotoxicity.

\section{Materials and methods}

\subsection{Materials}

The chemicals including Cisplatin (Catalogue Number-13119), KU-55933 (Catalogue Number-16336), were purchased from 
Cayman Chemical. All other cell culture media, reagents, serum, chemicals, plasmid pBR322 etc. were purchased from Merck India limited and Himedia Labs Pvt. Ltd. Mumbai, India.

\subsection{Cell culture, maintenance and cryopreservation of HeLa}

Cryopreserved HeLa were obtained from NCCS, Pune, India. These cells were thawed at $37^{\circ} \mathrm{C}$ and grown in DMEM (Dulbecco's Modified Eagles Medium) with 10\% FBS (Fetal Bovine Serum), antibiotic solution containing 10000 units of penicillin/10mg streptomycin with $5.0 \% \quad \mathrm{CO}_{2}$. Cells were constantly examined for signs of deterioration (change in $\mathrm{pH}$, morphology and density). HeLa were trypsinized from $75 \mathrm{~cm}^{2}$ culture flask and were centrifuged to form a uniform cell suspension. For the total cell count $10 \mu \mathrm{l}$ of suspended cells were observed on a hemocy tometer. For viability checking $10 \mu 1$ of cell suspension was mixed in equal amount of filter sterilized Trypan blue dye. Cell count was performed.

\subsection{Preparation of drugs/inhibitors}

Drug cisplatin was initially prepared as stock solution by dissolving $10 \mathrm{mg}$ in $500 \mu \mathrm{l} \mathrm{DMSO}$ and stored at $-20^{\circ} \mathrm{C}$. Final working concentration of cisplatin $(33 \mu \mathrm{M})$ was prepared and used in cell based assay. The KU-55933 inhibitor was first prepared as stock concentration of $5 \mathrm{mM}$ by dissolving $1 \mathrm{mg}$ powder in $500 \mu \mathrm{l}$ DMSO and stored at $-20{ }^{\circ} \mathrm{C}$. The final working solution of $\mathrm{KU}-$ 55933 was used in all cell-based assays at $2.5 \mu \mathrm{M}$ concentration.

\subsection{Trypan blue dye exclusion assay to determine ef- fects of ku-55933 towards cisplatin toxicity}

The HeLa were grown up to $80-90 \%$ confluenecy was harvested and plated on xix well plate at the seeding density of 200,000 cells per well. The media volume was kept at $2 \mathrm{ml}$ and was allowed to grow for next 16-18 h. Next day, overnight grown wells were treated in triplicates as DMSO control, cisplatin $(33 \mu \mathrm{M})$, and cisplatin $(33 \mu \mathrm{M})+\mathrm{KU}-55933(2.5 \mu \mathrm{M})$ in complete DMEM media. The drug and inhibitor were incubated for $48 \mathrm{~h}$ at $37^{\circ} \mathrm{C}$ in $\mathrm{CO}_{2}$ incubator. After incubation, media were removed and stored if any floating cells are recovered in the aspirated media. Then, wash with PBS, added with 0.3-0.5 ml 0.25\% tryp $\sin /$ EDTA for 2 $3 \mathrm{~min}$ in incubator. Further, added $2 \mathrm{ml}$ media to inactivate trypsin and collect in $2 \mathrm{ml}$ Eppendorf tube and centrifuge for $2 \mathrm{~min}$ at $8000 \mathrm{rpm}$. Ten $\mu 1$ of Trypan blue dye is mixed with $10 \mu 1$ of cell suspension. Then, cells were counted using standard protocol of hemocy tometer assay for viable and dead cells.

\subsection{MTT based cytotoxicity of cisplatin in combination with $\mathrm{ku}-55933$}

The $80-90 \%$ confluent HeLa were plated on 96 well plate with the seeding density of 5000 cells per well. After $16-18 \mathrm{~h}$ of seeding, drug Cisplatin / inhibitors (SCR7, KU-55933) along with $200 \mu \mathrm{l}$ complete MEM media were added and incubate for $48 \mathrm{~h}$ at $37^{\circ} \mathrm{C}$ in $\mathrm{CO}_{2}$ incubator. Volume and concentration of drug and inhibitors should be predetermined and premixed with the media. For MTT assay standard protocol was followed with slight modifications as fresh RPMI (without phenol red) was used. After the purple formazan crystal was precipitated, the microscopy photograph was taken using inverted microscope at $10 \mathrm{X}$ objective.

\subsection{DNA metabolizing activity of protein lysates from inhibitor/ drug treated HeLa}

The plasmid DNA degradation assay was performed to assess the DNA break ability of cisplatin drug and effect of HeLa lysates. One $\mu$ l of pBR322 plasmid DNA (100 ng / $\mu \mathrm{l})$ and one $\mu \mathrm{g}$ of plasmid DNA pBR322 were mixed with $2 \mu$ each of TAE buffer (Tri-
acetate/EDTA $10 \mathrm{mM}, \mathrm{pH}$ 7.4). Then after, different concentration of cisplatin drug ranging from $10 \mu \mathrm{M}$ to $500 \mu \mathrm{M}$ (final concentration) was added to the reaction mixture. Final volume of each reaction mixture was brought to $25 \mu$ by addition of nuclease free water in a microcentrifuge tube. Reaction mixtures were incubated for $24 \mathrm{~h}$ at $37^{\circ} \mathrm{C}$. In a separate experiment, with $50 \mu \mathrm{M}$ cisplatin treated plasmid DNA sample, we also included whole cell protein lysates obtained from treated $\mathrm{HeLa}$ as DMSO control, cisplatin $(33 \mu \mathrm{M})$, cisplatin $(33 \mu \mathrm{M})+\mathrm{KU}-55933(2.5 \mu \mathrm{M})$ from cell based experiment. At the end of experiment, the standard ethidium bromide stained gel was used to assess the DNA shearing or ligation activity due to cell lysates presence.

\subsection{The Flow cytometry based propidium iodide based cell viability assay}

HeLa were grown in three replicates of $35 \mathrm{~mm}^{2}$ culture dishes at a seeding density of 200,000 cells/dishes. After the treatment period, $2 \mathrm{ml} 500 \mu 1$ Trypsin-EDTA (Gibco) was added to each dish for 3-4 min until all cells had detached. The cell suspension was then added to $15 \mathrm{ml}$ Falcon tubes and centrifuged at $6000 \times \mathrm{g}$ for $3 \mathrm{~min}$. The supernatant was removed and the pellet washed with HBSS solution. Cells were centrifuged and the supernatant was removed. Further, $10 \mu 1 \mathrm{PI}$ added from a stock of $50 \mathrm{mg} / \mathrm{ml}$ to final concentration of $10 \mathrm{mg} / \mathrm{ml}$. Further, incubated for $30 \mathrm{~min}$ and then centrifuged to get the pellet. The pellet was again washed using PBS two times. Then, pellets were suspended in BD staining buffer and analyzed on the flow cytometer (BD FACSJazz). A minimum of 10,000 events were collected and analyzed using a $488 \mathrm{~nm}$ laser and 610LP, 616/23BP emission filters. PI inclusion signified loss in membrane integrity and cell death. Values were represented as percentage with reference to control.

\subsection{Statistical analysis}

The experiments were independently conducted three times. Results are expressed as mean \pm SD. Data from the different assays were statistically compared using one pair t-test as Microsoft office excel 2010 statistical package. Statistical significance was acceptable to a level of $\mathrm{p}<0.05$.

\section{Results and discussion}

Nowadays, chemotherapeutic treatment for surmounting cancerous cell using some chemicals, drugs and inhibitors are designed to achieve better success by generating DNA lesions in carcinoma genome (Hanahan and Weinberg, 2000; Jackson, 2002; Lieber, 2010; Schnitt, 2010; Chapman et al., 2012; Kavanagh et al., 2013; Aparicio et al., 2014; Álvarez-Quilón et al., 2014; Jeggo and Löbrich, 2015; Ceccaldi et al., 2016). Even if DNA damage is $100 \%$ as in case of certain chemotherapy drug regimen but the outcome and prognosis are not as per the expectations. Cancer generally generates acquired resistance to almost all chemotherapeutic drugs via a variety of various mechanisms and pathways also related with side effects (Jackson, 2002; Lieber, 2010; Álvarez-Quilón et al., 2014). Chemotherapeutic resistance whether it is acquired or intrinsic is sustained by alteration in drug targets and signal transduction molecules, increased repair of drug-induced DNA damage (Jackson, 2002; Lieber, 2010; Álvarez-Quilón et al., 2014).

\subsection{Trypan blue dye exclusion and MTT assay to de- termine effects of ku-55933 towards cisplatin toxicity}

The photomicrograph presented in Figure 1A show total cell count for HeLa cell during different drugs/inhibitors treatment condition. The corresponding total cell count using hemocy tometer was performed and data is given in Figure 1B. Data indicated that cisplatin responds to arrest HeLa growth some extent. Simultaneous treatment of KU-55933 resulted into accentuated reduction in total HeLa cell count. For the same in vitro HeLa drug treatment assay, 
we conducted Trypan blue exclusion assay to observe the extent of dead and viable cell. The microscopy photographs presented in Figure 2A depicts the Trypan blue dye uptake from the growing HeLa treated with or without cisplatin/KU-55933. We also estimated the dead cell count using hemocy tometer and data are pre- sented as bar graph in Figure 2B. The Trypan blue dye exclusion assay is widely accepted to understand the anticancer activity including anti-proliferative and cytotoxic activity (Strober, 2001, Kristine et al., 2011).

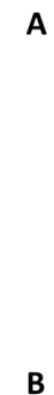

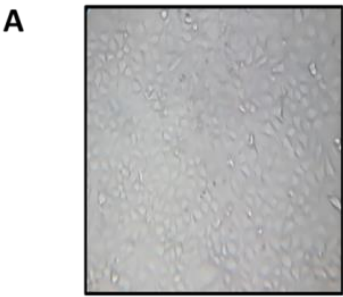

DMSO Control

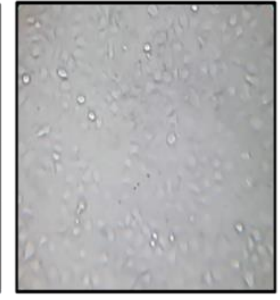

Cisplatin

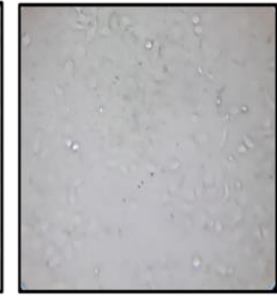

Cisplatin +

B

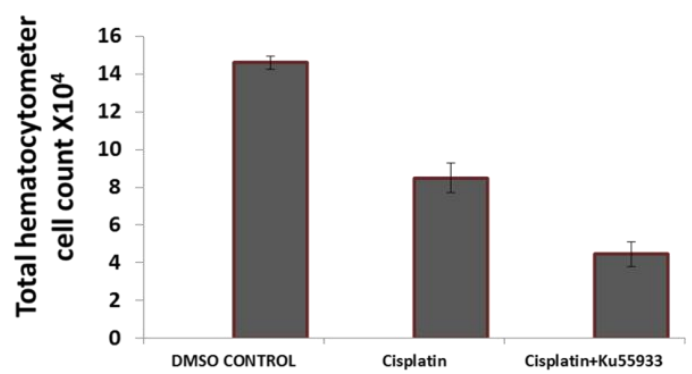

Fig. 1: Hemocytometer and Microscopy Based HeLa cell Proliferation Data Is Presented. (A). This Diagram Represents the Photomicrograph Taken at 10X for HeLa Growing in Six Well Plate with Different Treatment Condition Whereas DMSO Control, Cisplatin $33 \mu \mathrm{M})$ and Cisplat in $(33 \mu \mathrm{M})+\mathrm{KU}-$ $55933(2.5 \mu \mathrm{M})$. The Microscopy Photographs were taken at the End of Drugs/Inhibitors Treatment for $48 \mathrm{H}$. at the End of Treat ment; The Microscopy Photograph was Captured Using Light Inverted Microscope. The Data are represented as Mean \pm SD. Each Experiment Was Conducted Independently Three Times. (B). This Diagram Is A Representative Bar Graph Data for HeLa Cell Growing in Six Well Plate with Different Treatment Condition Whereas DMSO Control, Cisplatin $33 \mu \mathrm{M})$ and Cisplatin $(33 \mu \mathrm{M})+\mathrm{KU}-55933(2.5 \mu \mathrm{M})$. The Total Cells were Recorded Using Hemocytometer and Data Is Presented as Percentage of T otal Cell Count X10 In Each Treatment Conditions.

To our surprise, we found none significant HeLa cytotoxicity as determined from dead cell count data and microscopy data. Herein, Trypan blue dye exclusion data indicated that KU-55933 can efficiently synergies and accentuate the effect of cisplatin anti-proliferative effect against HeLa.

A
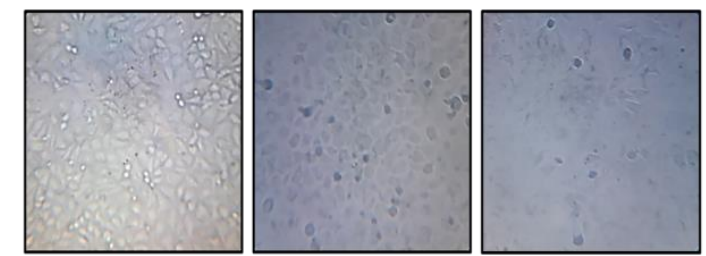

B

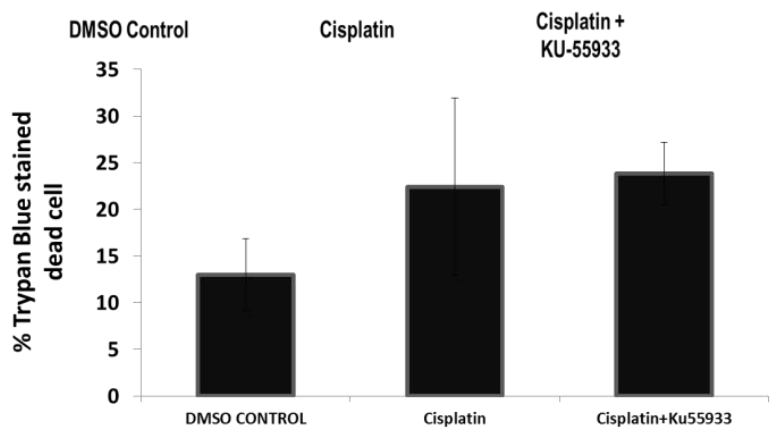

Fig. 2: This Data Represented the Trypan Blue Dye Exclusion Assay Results Obtained from HeLa Drug Toxicity Assay. (A) This Is A Representative Photomicrograph Taken at 10X for HeLa Cell Growing in 96 Well Plate with Different Treatment Condition Whereas DMSO Control, Cisplat in $33 \mu \mathrm{M}$ ) and Cisplat in $(33 \mu \mathrm{M})+$ KU-55933 $(2.5 \mu \mathrm{M})$. The Microscopy Photograph were Taken after Trypan Blue Dye Exclusion Assay Staining in the Well, Where Cells Were Growing under Different Treatment Conditions. The Data are represented as Mean \pm SD. Each Experiment was Conducted Independently Three Times. (B). This Diagram Is A Representative Bar Graph Data for HeLa Cell Growing in Six Well Plate with Different Treatment Condition Whereas DMSO Control, Cisplatin $33 \mu \mathrm{M})$ and Cisplat in $(33 \mu \mathrm{M})+\mathrm{KU}-55933(2.5 \mu \mathrm{M})$. The Total Cell and Viable Cell Count were Recorded Using Hemocytometer and Dat a Is Presented as Percentage of Viable Cell in Each Treatment Condition. The Data are represented as Mean \pm SD. Each Experiment was Conducted Independently Three Times.

The results presented in Figure 3 represent the microscopy photographs taken at the end of MTT based cell growth and viability assay. The analy sis of microscopy data point out that addition of KU-55933 along with cisplatin could not elicit cell cytotoxicity as intensity of MTT based colored formazan crystal production showed no difference. Hence, MTT based assay data supports Trypan blue dye exclusion assay results showing no discernible increase in the cell cy totoxicity due to combined effects of cisplatin and KU-55933. 


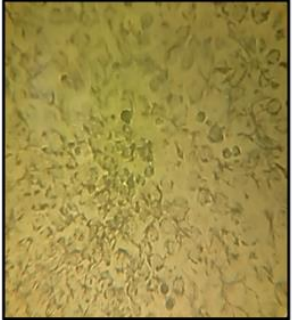

DMSO Control

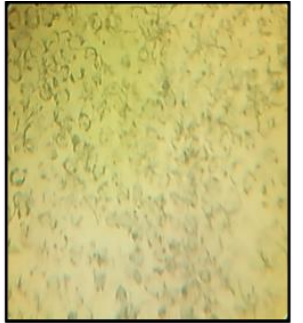

Cisplatin

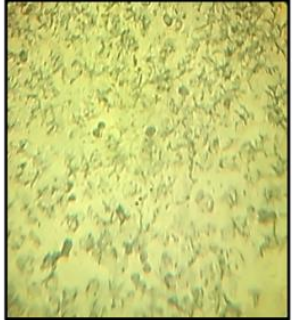

Cisplatin +

KU-55933

Fig. 3: The Photograph Depicts the Photomicrograph Taken at 10X for HeLa Cell Growing in 96 WellPlate with Different Treatment Condition Whereas DMSO Control, Cisplatin $33 \mu \mathrm{M})$ and Cisplatin $(33 \mu \mathrm{M})+\mathrm{KU}-55933(2.5 \mu \mathrm{M})$. The Microscopy Photographs were Taken at the End of MTT Based Assay with Formazan Colored Using 10 X Objective.

\subsection{In vitro DNA metabolizing activity of protein ly- sates}

The in vitro DNA damage ability of cisplatin was assessed using plasmid DNA pBR322 based nicking/shearing. The results as ethidium bromide stained gel photographs are depicted in Figure 4A. However, we did not observe clear nicking or shearing of plasmid DNA substrate ranging from $20 \mu \mathrm{M}$ to $100 \mu \mathrm{M}$, but at $500 \mu \mathrm{M}$ some shearing damage is observed. We conclude that our results are in consonance with earlier reports that at low concentration cisplatin may not bring clear nicking or damage to DNA (Inoue et al., 2014; Ha et al., 2014; Tonsing-Carter et al., 2015; Toulany et al., 2015). Therefore, we performed in vitro cell based experiment at $33 \mu \mathrm{M}$ cisplatin concentration which is less genotoxic and possibly with fewer side effects. Further, we asked whether cell lysates obtained in vitro HeLa cell based treatment could possess differential DNA metabolizing activity towards plasmid DNA pBR322 substrate treated with cisplatin at $50 \mu \mathrm{M}$. The agarose DNA ethidium bromide stained gel is presented in Figure 4B. Data indicated that HeLa whole cell ly sates possessed significant DNA metabolizing activity compared to cisplatin drug treated control. To our notice, the data demonstrated that in case of cell lysates from cisplatin plus KU-55933 produced more nicking of plasmid DNA substrate over only cisplatin treated HeLa lysates. Therefore, we tried to explain that cisplatin plus KU55933 treated HeLa lysates may have less active pool of DNA double strand break repair proteins over the cisplatin alone treated HeLa lysates. Such probable difference might lead to the clear difference in the DNA damage/shearing pattern in the plasmid DNA pBR322.

\section{A}

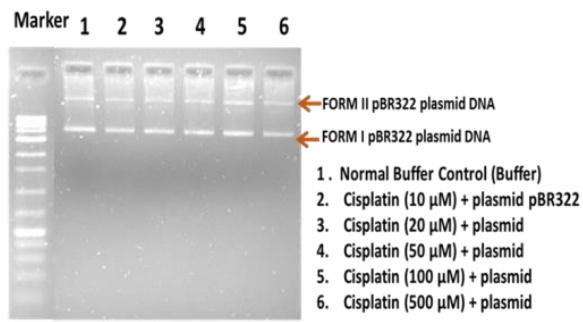

B

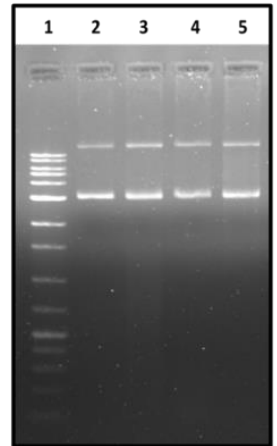

1. DNA Ladder

2. Plasmid $\mathrm{pBR} 322$ with buffer and Cisplatin $(50 \mu \mathrm{M})$

3. Plasmid pBR322 with Cisplatin and DMSO treated Hela protein lysate

4. Plasmid pBR322 with Cisplatin and Cisplatin treated HeLa protein lysate

5. Plasmid pBR322 with Cisplatin and Cisplatin $+\mathrm{KU}$ 55933 treated HeLa protein lysate

Fig. 4: (A) This Agarose Gel Photograph Shows the Plasmid DNA Damage Assay Result against Cisplat in Treatment Ranging from $20 \mu \mathrm{M}$ to $500 \mu \mathrm{M}$. The Reaction was performed at $16^{\circ} \mathrm{C}$ in TAE Buffer and Its Composition Is Described in Method Section. The Dat a are represented as Mean \pm SD. Each Experiment was Conducted Independently Three Times. Figure 4 (B). This Gel Photograph is A Representative Agarose DNA Gel Stained for Pbr322 Plasmid Treated with HeLa Whole Cell Lysates Extracted from in Vitro Treated Cell Based Assay as DMSO Control, Cisplatin (33 $\mu$ M) and Cisplatin (33 $\mu \mathrm{M})+\mathrm{KU}-55933(2.5 \mu \mathrm{M})$ as Mentioned in the Method Section and Cisplatin $(50 \mu \mathrm{M})$. Each Experiment was Conducted Independently Three Times.

\subsection{Flow cytometer analysis of cis platin treated HeLa cell}

The flow cytometer analysis of cisplatin and cisplatin combined with KU-55933 inhibitor in HeLa were analyzed by PI based staining. The results are presented in Figure 5 A-D. Results analysis showed that in case of cisplatin-treated HeLa sample apoptotic based PI stained cell percentage was not significant compared to untreated control. In case of cisplatin along with KU-55933, we found none noticeable presence of PI stained cell. On other hand, we compared with positive control of doxorubicin plus SCR-7 (Ajay et al., 2016) noticed with existence of PI stained HeLa. Hence, our data strongly suggest that cisplatin and cisplatin combined with KU-55933 did not result into apoptotic cell death. Our observations may rely upon cell cycle arrest and anti-proliferative mechanisms. 


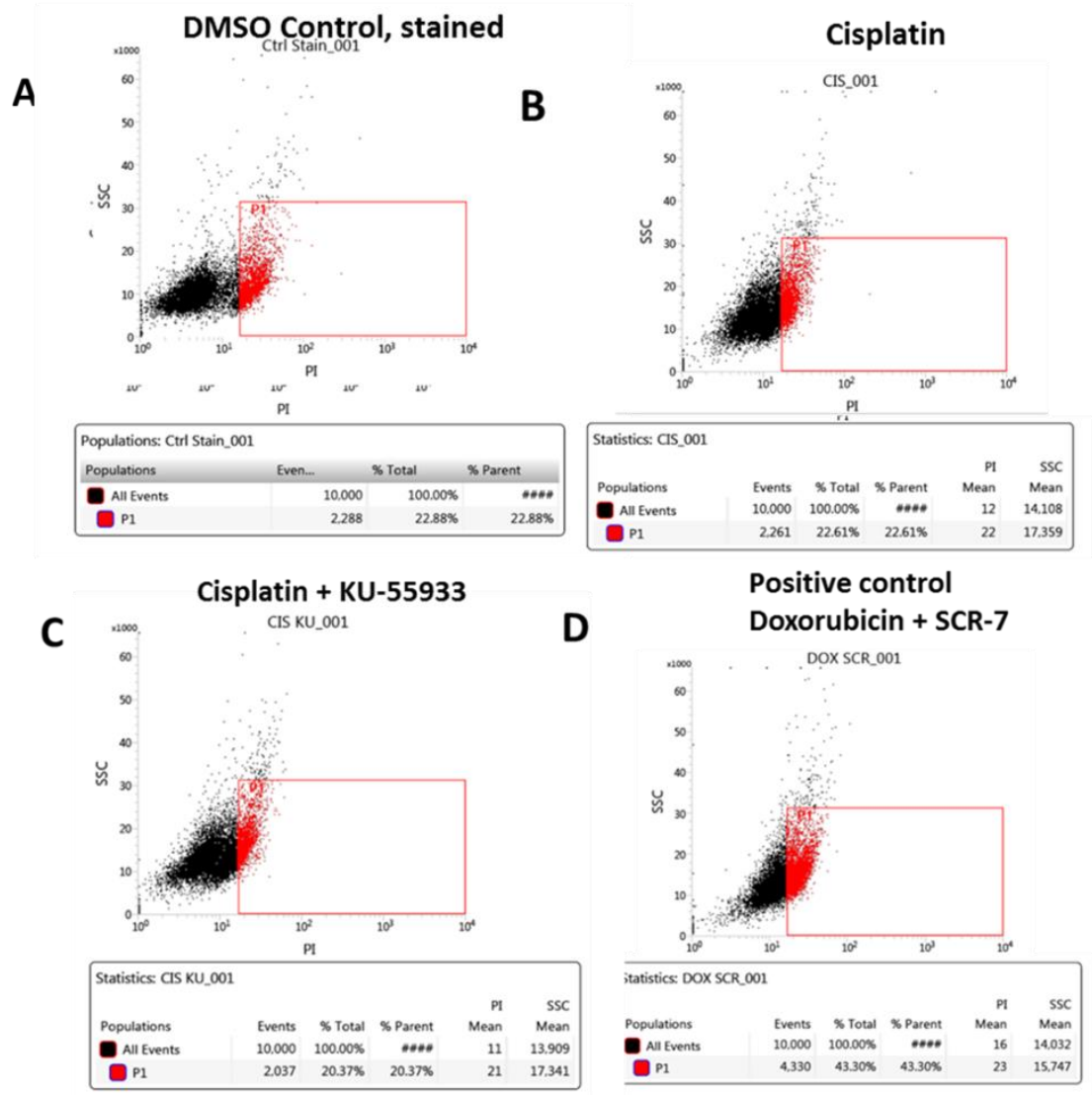

Fig. 5: This Diagram Presents the Flow Cytometer Based Cell Viability Data. (A) This Data Represents the PI Based Flow Cytometer Results for Untreated DMSO Control HeLa. (B). PI Based Cell Viability Data for Cisplatin $33 \mu \mathrm{M}$ Treated HeLa. (C). PI Based Cell Viability Data for Cisplat in $(33 \mu \mathrm{M})+$ KU-55933 (2.5 $\mu \mathrm{M})$ Treated HeLa. (D). PI Based Cell Viability Data for Positive Control Doxorubicin (25 nM) + SCR-7 (29.8 $\mu$ M) Treated HeLa. The Experiments were conducted in Triplicates.

It is widely accepted that cisplatin modulates ataxia-telan giectasia-mutated (ATM), a protein with clear role in double strand DNA repair, cell cycle progression and autophagy. In earlier study, evidences have suggested that KU-55933, an ATM kinase inhibitor may be able to push non-small lung cancer towards augmented radiosensitization (Toulany et al., 2015). Cisplatin is the main chemotherapeutic drug regimen for the treatment of cervical cancers. However, resistance to cisplatin is increasingly common and therefore found to have limited the efficacy and use of this drug in the clinic. Dose-dependent toxicity poses an additional challenge since patients suffer long-term and often permanent side-effects after treatment. Recently, Leisching et al (2015) have reported that cisplatin at $15 \mu \mathrm{M}$ displayed low cytotoxicity activity due to the inherent cellular capability of HeLa. In agreement, present study using cisplatin at $33 \mu \mathrm{M}$ demonstrated less anti-proliferative activity against HeLa.

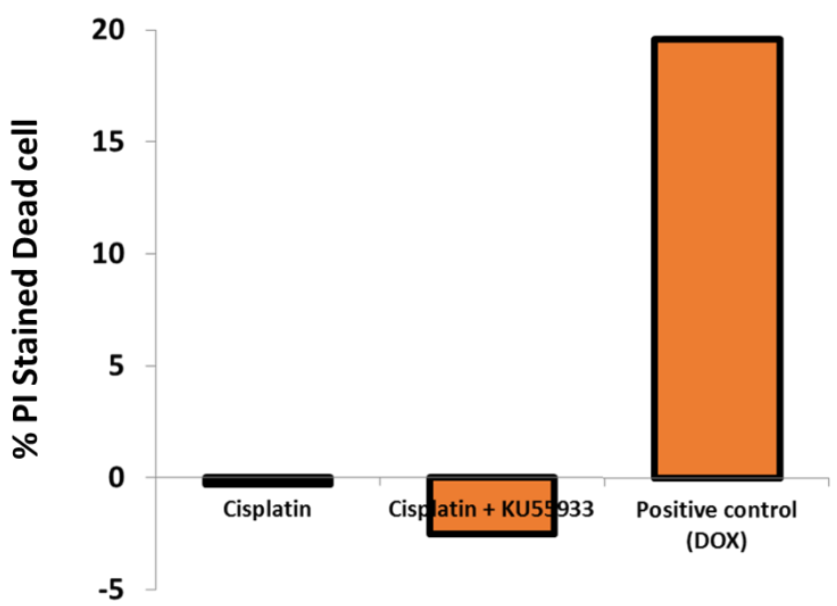

Fig. 5: (E) This Data Represents the PI Based Flow Cytometer Percentage PI Stained HeLa cell Over the DMSO Control. The Data are calculated from Flow Cytometer Cell Viability Data Presented in Figure 5 A-D.

We agree to earlier views that in case of HeLa responses against cisplatin may be modulated by the DSB pathways. When designated inhibitor as KU-55933 used along with, we found synergistic effects to show anti-proliferative potential. Therefore, DSB repair pathway ATM inhibitor KU-55933 may be a right candidate to test in combination with the cisplatin to see better responsiveness (Hickson et al., 2004; Srivastava et al., 2012; Surovtseva et al., 2016; Srivastava and Raghavan, 2015; Vecchio and Frosina , 2016; Weterings et al., 2016). Besides, there are reports on resistance towards DNA crosslinking agents such as cisplatin to be 
linked with ERCC1 and FANC-BRCA1 pathway. Simultaneously, it is indicated that inactivation and deactivation such DNA repair protein may prove an option for better cisplatin based cell death response (Curtin, 2012; Puigvert et al., 2016).

There are ample evidences showing DNA double-strand breaks (DSBs) are formed during the processing of DNA inter-strand crosslinks due to treatment to cisplatin in case of proliferating HeLa. Thus, DNA inter-strand crosslinks induced by different crosslinking agents, including cisplatin may be processed and y ielding to DSBs as an intermediate lesion (Inoue et al., 2014; Ha et al., 2014; Tonsing-Carter et al., 2015; Toulany et al., 2015; Ceccaldi et al., 2015). To extend and support such views, our cell cytotoxicity data point out that double strand break repair inhibitor KU-55933 demonstrated significant contribution to stop the growth of HeLa. Such findings may be due to interfering in double strand break repair signaling pathway and leading to occurrence of more lethal damage as double strand break.

\section{Conclusion}

In conclusion, our data provide evidences for the combinatorial option encompassing KU-55933 an ATM kinase inhibitor combined with cisplatin displaying reduction in HeLa cell proliferation. However, KU-55933 showed as anti-proliferative instead of apoptotic cell cytotoxicity to act in synergy with cisplatin. We envision that exploring detailed molecular mechanisms in HeLa and other cancer types keeping may lead to DNA repair profile based therapy.

\section{Acknowledgements}

We would like to thank the Cancer Biology Research Group for their constant support and motivation and our host institute Dr. D. Y. Patil Biotechnology \& Bioinformatics Institute, Dr. D. Y Patil Vidyapeeth, Pune for providing resources. The authors acknowledge the financial support from DST-SERB, New Delhi, India and DPU, Pune, India. We acknowledge CRF, DPU, Pune facility for Flow cytometer facility

\section{Declaration of interest}

Authors declare no conflict of interest.

\section{References}

[1] Albarakati N, Abdel-Fatah TM, Doherty R, Russell R, Agarwal D, Moseley P, Perry C, Arora A, Alsubhi N, Seedhouse C et al. 2015. Target ing BRCA1-BER deficient cancer by ATM or DNA-PKcs blockade either alone or in combination with cisplat in for personalized therapy. Mol Oncol. 9(1):204-17. http://dx.doi.org/10.1016/i.molonc.2014.08.001.

[2] Álvarez-Quilón A, Serrano-Benítez A, Lieberman JA, Quintero C, Sánchez-Gutiérrez D, Escudero LM, Cortés-Ledesma F. 2014. ATM specifically mediates repair of double-strand breaks with blocked DNA ends. Nat Commun. 5:3347. http://dx.doi.org/10.1038/ncomms4347.

[3] Andrs M, Korabecny J, Nepovimova E, Jun D, Hodny Z, Kuca K 2016. Small Molecules Targeting Ataxia Telangiectasia and Rad3Related (ATR) Kinase: An Emerging way to Enhance Existing Cancer Therapy. Curr Cancer Drug Targets. 16(3):200-8 http://dx.doi.org/10.2174/156800961603160206122927.

[4] Aparicio T, Baer R, Gautier J. 2014. DNA double-strand break repair pathway choice and cancer. DNA repair. 19:169-75. http://dx.doi.org/10.1016/j.dnarep.2014.03.014.

[5] Braunstein LZ, Taghian AG. Molecular Phenotype, Multigene Assays, and the Locoregional Management of Cancer. 2016. Semin Radiat Oncol. http://dx.doi.org/10.1016/j.semradonc.2015.08.002.

26(1):9-16

[6] Ceccaldi R, O'Connor KW, Mouw KW, Li AY, Matulonis UA D'Andrea AD, Konstantinopoulos PA. 2015. A unique subset of epithelial ovarian cancers with platinum sensitivity and PARP inhibi- tor resistance. Cancer Res. 75(4):628-34 http://dx.doi.org/10.1158/0008-5472.CAN-14-2593.

[7] Ceccaldi R, Rondinelli B, D'Andrea AD. 2016. Repair Pathway Choices and Consequences at the Double-Strand Break. Trends Cell Biol. 26(1):52-64. http://dx.doi.org/10.1016/j.tcb.2015.07.009.

[8] Chapman JR, Taylor MR, Boulton SJ. 2012. Playing the end game DNA double-strand break repair pathway choice. Mol Cell 47(4):497-510. http://dx.doi.org/10.1016/j.molcel.2012.07.029.

[9] Curt in, N. J. 2012. DNA repair dy sregulation from cancer driver to therapeutic target. Nature Reviews Cancer. 12(12):801-817. http://dx.doi.org/10.1038/nrc3399.

[10] De Bont R and van Larebeke N. 2004. Endogenous DNA damage in humans: a review of quantitative data. Mutagenesis. 19(3):169185. http://dx.doi.org/10.1093/mutage/geh025.

[11] Flores-Pérez A, Rafaelli LE, Ramírez-Torres N, Aréchaga-Ocampo E, Frías S, Sánchez S4, Marchat LA, Hidalgo-Miranda A, Quintanar-Jurado V, Rodríguez-Cuevas S, Bautista-Piña V, et al. 2014. RAD50 targeting impairs DNA damage response and sensitizes human cancer cells to cisplat in therapy. Cancer Biol Ther. 15(6):777-88. http://dx.doi.org/10.4161/cbt.28551.

[12] Gavande NS, VanderVere-Carozza PS, Hinshaw HD, Jalal SI, Sears CR, Pawelczak KS, Turchi JJ. 2016. DNA repair targeted therapy: The past or fut ure of cancer treatment? Pharmacol Ther. pii: S0163-7258(16)00032-2. 10.1016/j.pharmthera.2016.02.003. http://dx.doi.org/10.1016/j.pharmthera.2016.02.003.

[13] Ha K, Fiskus W, Choi DS, Bhaskara S, Cerchietti L, Devaraj SG, Shah B, Sharma S, Chang JC, Melnick Am et al. 2014. Histone deacetylase inhibit or treatment induces 'BRCAness' and synergistic lethality with PARP inhibitor and cisplatin against human triple negative cancer cells. Oncotarget. 5(14):5637-50. http://dx.doi.org/10.18632/oncotarget.2154.

[14] Hanahan D, Weinberg RA. 2000. The hallmarks of cancer. Cell. 100(1):57-70. http://dx.doi.org/10.1016/S0092-8674(00)81683-9.

[15] Hickson I, Zhao Y, Richardson CJ, Green SJ, Mart in NM, Orr AI, Reaper PM, Jackson SP, Curt in NJ, Smith GC. 2004. Identification and characterization of a novel and specific inhibitor of the ataxiatelangiectasia mutated kinase ATM. Cancer Res. 64(24):9152-942. http://dx.doi.org/10.1158/0008-5472.CAN-04-2727.

[16] Hitrik A, Abboud-Jarrous G, Orlovetskie N, Serruya R, Jarrous N. 2016. Targeted inhibition of WRN helicase by external guide sequence and RNase P RNA. Biochim Biophys Acta. 1859(4):572580 .

[17] Hong KJ, Hsu MC, Hung WC. 2015. RECK impedes DNA repair by inhibiting the erbB/JAB1/Rad51 signaling axis and enhances chemosensitivity of cancer cells. Am J Cancer Res. 5(8):2422-30.

[18] Huang F, Goyal N, Sullivan K, Hanamshet K, Patel M, Mazina OM, Wang CX, An WF, Spoonamore J, Metkar S et al. 2016. Target ing BRCA1 - and BRCA2-deficient cells with RAD52 small molecule inhibitors. Nucleic Acids Res. pii: gkw087. [Epub ahead of print]. http://dx.doi.org/10.1093/nar/gkw087.

[19] Inoue A, Kikuchi S, Hishiki A, Shao Y, Heath R, Evison BJ, Act is M, Canman CE, Hashimoto H, Fujii N. 2014. A small molecule inhibitor of monoubiquitinated Proliferating Cell Nuclear Antigen (PCNA) inhibits repair of interstrand DNA cross-link, enhances DNA double strand break, and sensitizes cancer cells to cisplat in. J Biol Chem. http://dx.doi.org/10.1074/ibc.M1 13.520429.

[20] Jackson SP, Bartek J. 2009. The DNA-damage response in human biology and disease. Nature. 461(7267):1071-8. http://dx.doi.org/10.1038/nature08467.

[21] Jackson SP. 2002. Sensing and repairing DNA double-strand breaks. Carcinogenesis. http://dx.doi.org/10.1093/carcin/23.5.687.

[22] Jeggo PA, Löbrich M. 2015. How cancer cells hijack DNA doublestrand break repair pathways to gain genomic instability. Biochem $\mathrm{J}$ 471(1):1-11. http://dx.doi.org/10.1042/BJ20150582.

[23] Jekimovs G, Bolderson E, Suraweera A, Adams M, O'Byrne KJ, Richard DJ. 2014. Chemotherapeutic compounds targeting the DNA double-strand break repair pathways: the good, the bad, and the promising. Front Oncol. 4:86. http://dx.doi.org/10.3389/fonc.2014.00086.

[24] Kavanagh, J.N. Redmond, K.M. Schettino, G. and Prise, K.M. 2013 DNA double strand break repair: a radiation perspective. Antioxidants \& redox signaling, 18(18), pp.2458-2472.

[25] Kelley MR, Logsdon D, Fishel ML. 2014. Targeting DNA repair pathways for cancer treatment: what's new? Future Oncol. 10(7):1215-1237. http://dx.doi.org/10.2217/fon.14.60. 
[26] Khanna A. 2015. DNA damage in cancer therapeutics: a boon or a curse? Cancer Res. 5(11):2133-8. http://dx.doi.org/10.1158/00085472.CAN-14-3247.

[27] Kimbung S, Loman N, Hedenfalk I. 2015. Clinical and molecular complexity of cancer metastases. Semin Cancer Biol.35:85-95. http://dx.doi.org/10.1016/i.semcancer.2015.08.009.

[28] Kristine S. Louis and Andre C. Siegel. 2011. Cell Viability Analysis Using Trypan Blue: Manualand Automated Methods. A book chapter in Martin J. Stoddart (ed.), Mammalian Cell Viability: Methods and Protocols, Methods in Molecular Biology, vol. 740, DOI 10.1007/978-1-61779-108-6_1, (C) Springer Science+Business Media, LLC 2011.

[29] Leisching G, Loos B, Botha M, Engelbrecht AM. 2015. Bcl-2 confers survival in cisplat in treated cervical cancer cells: circumventing cisplatin dose-dependent toxicity and resistance. J Transl Med. 13:328. doi: 10.1186/s12967-015-0689-4. http://dx.doi.org/10.1186/s12967-015-0689-4.

[30] Lieber MR. 2010. The mechanism of double-strand DNA break repair by the nonhomologous DNA end-joining pathway. Annu Rev Biochem. 2010; 79: 181-211. http://dx.doi.org/10.1146/annurev.biochem.052308.093131.

[31] Liu F, Suryadi J, Bierbach U. 2015. Cellular Recognition and Repair of Monofunctional-Intercalative Platinum--DNA Adducts. Chem Res Toxicol. 28(11):2170-8. http://dx.doi.org/10.1021/acs.chemrestox.5b00327.

[32] Liu Y, Li Y, Lu X. 2016. Regulators in the DNA damage response. Arch Biochem Biophys. 15; 594:18-25. http://dx.doi.org/10.1016/j.abb.2016.02.018.

[33] Mladenov E, Magin S, Soni A, Iliakis G. 2016. DNA doublestrand-break repair in higher eukaryotes and its role in genomic instability and cancer: Cell cycle and proliferation-dependent regulation. Semin Cancer Biol. pii: S1044-579X (16)30007-4. doi 10.1016/j.semcancer.2016.03.003. http://dx.doi.org/10.1016/i.semcancer.2016.03.003.

[34] O'Connor MJ. 2015. Targeting the DNA Damage Response in Cancer. Mol Cell. 60(4):547-560. http://dx.doi.org/10.1016/i.molcel.2015.10.040.

[35] Puigvert JC, Sanjiv K, Helleday T. 2016. Targeting DNA repair, DNA metabolism and replication stress as anti-cancer strategies. FEBS J. 283(2):232-45. http://dx.doi.org/10.1111/febs. 13574.

[36] Rajamanickam S, Panneerdoss S, Gorthi A, Timilsina S, Onyeagucha B, Kovalsky D, Ivanov D, Hanes MA, Vadlamudi RK, Chen $\mathrm{Y}$ et al. 2016. Inhibition of FOXM1-Mediated DNA repair by Imipramine Blue Suppresses Cancer Growth and Metastasis. Clin Cancer Res. 2016 Feb 29. pii: clincanres.2535.2015.

[37] Ratner ES, Zhu YL, Penketh PG, Berenblum J, Whicker ME, Huang PH, Lee Y, Ishiguro K, Zhu R, Sart orelli AC, Lin ZP. 2016. Triapine potentiates platinum-based combination therapy by disruption of homologous recombination repair. Br J Cancer. 114(7):777786. http://dx.doi.org/10.1038/bjc.2016.54.

[38] Samadder P, Aithal R, Belan O, Krejci L. 2016. Cancer T ARGETases: DSB repair as a pharmacological target. Pharmacol Ther. 2016 Feb 18. pii: S0163-7258(16)00036-X. doi: 10.1016/j.pharmthera.2016.02.007. http://dx.doi.org/10.1016/i.pharmthera.2016.02.007.

[39] Schnitt SJ. 2010. Classification and prognosis of invasive cancer: from morphology to molecular taxonomy. Modern Pathology. 2010. 23, S60-S64 http://dx.doi.org/10.1038/modpathol.2010.33.

[40] Srivastava M, et al. 2012. An inhibitor of nonhomologous endjoining abrogates double-strand break repair and impedes cancer progression. Cell. 151:1474-1487. http://dx.doi.org/10.1016/j.cell.2012.11.054.

[41] Srivastava M, Raghavan SC. 2015. DNA double-strand break repair inhibitors as cancer therapeutics. Chem Biol. 22(1):17-29. 40.

[42] Strober W. 2001. Trypan blue exclusion test of cell viability. Curr Protoc Immunol. 2001 May;Appendix 3:Appendix 3B. doi: 10.1002/0471142735.ima03bs21. http://dx.doi.org/10.1002/0471142735.ima03bs21.

[43] Surovtseva YV, Jairam V, Salem AF, Sundaram RK, Bindra RS, Herzon SB. 2016. Characterization of Cardiac Glycoside Natural Products as Potent Inhibitors of DNA Double-Strand Break Repair by a Whole-Cell Double Immunofluorescence Assay. J Am Chem Soc. 138(11):3844-55.http://dx.doi.org/10.1021/jacs.6b00162.

[44] Tonsing-Carter E, Bailey BJ, Saadatzadeh MR, Ding J, Wang H, Sinn AL, Peterman KM, Spragins TK, Silver JM et al. 2015. Potentiation of Carboplatin-Mediated DNA Damage by the Mdm2 Modulator Nutlin-3a in a Humanized Orthotopic -to-Lung Metastatic Model. Mol Cancer Ther. 14(12):2850-63. http://dx.doi.org/10.1158/1535-7163.MCT-15-0237.
[45] Toulany M, Mihatsch J, Holler M, Chaachouay H, Rodemann HP 2015. Cisplatin-mediated radiosensitization of non-small cell lung cancer cells is stimulated by ATM inhibition. Radiother Oncol. 111(2):228-36. http://dx.doi.org/10.1016/j.radonc.2014.04.001.

[46] Vecchio D, Frosina G. 2016. Targeting the Ataxia Telangiectasia Mutated Protein in Cancer Therapy. Curr Drug Targets. 17(2):13953. http://dx.doi.org/10.2174/1389450115666141110154621.

[47] Velic D, Couturier AM, Ferreira MT, Rodrigue, Poirier GG, Fleury F, Masson JY. 2015. DNA Damage Signalling and Repair Inhibitors: The Long-Sought-After Achilles 'heel of Cancer. Biomolecules. 5(4):3204-59 http://dx.doi.org/10.3390/biom5043204.

[48] Weterings E, Gallegos AC, Dominick LN, Cooke LS, Bartels TN, Vagner J, Mat sunaga TO, Mahadevan D. 2016. A novel small molecule inhibitor of the DNA repair protein Ku70/80.DNA Repair (Amst). 2016 Apr 7. pii: S1568-7864(15)30109-9. doi: 10.1016/j.dnarep.2016.03.014 http://dx.doi.org/10.1016/j.dnarep.2016.03.014.

[49] Zhang T, Shen Y, Chen Y, Hsieh JT, Kong Z. 2015. The ATM inhibitor KU55933 sensitizes radioresistant bladder cancer cells with DAB2IP gene defect. Int J Radiat Biol. 91(4):368-78. http://dx.doi.org/10.3109/09553002.2015.1001531. 